\title{
Sustainable Development of Territories Based on the Integrated Use of Industry, Resource and Environmental Potential
}

\author{
Submitted 20/02/19, $1^{\text {st }}$ revision 12/03/19, accepted 06/04/19 \\ O.Yu. Voronkova ${ }^{1}$, L.A. Iakimova ${ }^{2}$, I.I. Frolova ${ }^{3}$, Ch.I. Shafranskaya ${ }^{4}$, \\ S.G. Kamolov ${ }^{5}$, N.A. Prodanova ${ }^{6}$
}

\begin{abstract}
:
Purpose: Attention to the problems of social and economic development of rural areas by Government authorities, economists and the scientific community was mainly theoretical or sometimes targeted practical in nature.

Design/Methodology/Approach: At the same time, rural poverty and high unemployment rate, worsening demographic situation, reducing network of institutions of social infrastructure in rural areas, which together have a negative impact on the reproduction of labor resources, lower production volumes and high migration rates have always been the problems of rural development in the country.

Findings: Overall, sustainable development of rural areas characterizes, on the one hand, external major natural resource constraints that form a distant prospect, and on the other hand, determine the possibilities of social and economic development of rural communities, economic entities, diversification of the territory's economy, the formation of new activities and environmental engineering. This is a very wide range of problems, which are currently considered from different perspectives in Russia and in several countries of the world.

Practical implications: The article discusses the problems of economic development of rural areas as the main factor in ensuring the sustainable development of rural areas of the agrarian regions of Russia.

Originality/Value: The authors define the core resources for development of the rural areas in the region, provide an overview of agribusiness and tourism industry clusters, reveling their points of growth, cluster sales channels, tourism and recreation development.
\end{abstract}

Keywords: Rural area, sustainable development, cluster, resources, agribusiness, tourism, ecology.

JEL Classification: $013, Q 1, Q 18, R 11, R 58$.

Paper type. Research article.

\footnotetext{
${ }^{1}$ Altai state University, Barnaul, Russia. E-mail: olka2004@yandex.ru

${ }^{2}$ Krasnoyarsk agrarian University, Krasnoyarsk, Russian Federation.

${ }^{3}$ Kazan Innovative University named after V.G. Timiryasov (IEML), Kazan, Russia.

${ }^{4}$ Kazan Innovative University named after V.G. Timiryasov (IEML), Kazan, Russia.

${ }^{5}$ Moscow State Institute of International Relations (MGIMO), Moscow, Russia.

${ }^{6}$ Plekhanov Russian University of Economics, Moscow, Russia.
} 


\section{Introduction}

The World Conservation Strategy developed by the UN Committee on the Environment and the World Wildlife Fund was one of the first international documents mentioning the term "sustainable development". The strategy emphasized the need to consider environmental factors in the process of socio-economic development of territories. In 1983, under the aegis of the UN, the "Our Common Future" report was prepared, presenting the concept of sustainable social and economic development of territories in equilibrium with the environment for the first time ever (Alferova, 2015). The provisions of the report were the basis for the Declaration on Environment and Development, approved by the United Nations Conference in Rio de Janeiro in 1992. The declaration officially announced the thesis on the need to ensure a balanced solution of social and economic problems and the problems of preserving a favorable environment and natural resource potential in order to meet the needs of present and future generations (Kolesova, 2015; Podoprigora et al., 2016; Korobov and Raupov, 2017; Aleksandrova et al., 2017).

The solution to the problems of stable economic development and the well-being of the Russia people is largely determined by the development of rural areas (Sycheva et al., 2018; Poltarykhin et al., 2018; Ivanova et al., 2018; Aleksandrova et al., 2015; Nikolaeva et al., 2018). The focus on the model of sustainable rural development involves achieving social and economic stability, systematically increasing the efficiency of economic entities in the region, as well as rural income and quality of life; rational use of natural resources (Podprugin, 2012; Yarlykapov, 2013; Kovalenko, 2012). However, there is still no clear and understandable government reformation strategy contributing to sustainable development of the rural areas (Nagimov et al., 2018; Kopteva and Koptev, 2018; Koptev and Kopteva, 2017a).

\section{Methods}

The research is based on the study of sustainable development of the territories based on the integrated use of industry, resource and environmental potential, the formation of organizational and economic relations between the subjects of sustainable development (Korableva et al., 2018), in particular through the mechanism of territorial clustering (Polyakova et al., 2018; Sozinova et al., 2017; Akhmetshin et al., 2017a; 2017b). To achieve the objectives under study, the authors used critical analysis of literature sources and general scientific methods - a systematic approach, methods of analogies, abstract, logical, monographic, statistical and economic methods. Systematic approach served as a methodological basis for this study, which allowed ensuring the comprehensive and targeted character of the study. 


\section{Results}

Sustainable rural development is often confused with steady rural sustenance. These concepts are closely interrelated; however, the concept of sustainable development of rural areas is much broader, as it includes the socio-economic and environmental aspects of agriculture and rural landscaping in general (Danilov-Danilian, 2003; Akhmetov et al., 2009; Poltarykhin et al., 2018; Voronkova et al., 2018c). At the same time, the villager, his needs and interests are at the center steady rural sustenance system. Moreover, the sustenance itself is associated with improving the quality of life of the rural population (Rozenberg, 2005). While considering a rural territory as a system several scientists distinguish three subsystems: economic, social and environmental, each of which can also be presented as a separate system consisting of a set of elements (Polushkina, 2012; Sycheva et al., 2015; Voronkova et al., 2018a; 2018b; Korobov and Podoprigora, 2018; Podoprigora and Korobov, 2017; Podoprigora and Saychenko, 2017). The indicated approach is quite consistent with the paradigm of sustainable development; in which it is considered in the context of three components. When considering rural areas as socio-ecologicaleconomic systems, one can distinguish the following structural elements (Voronkova et al., 2018a; 2018b):

1. Rural area as a basis for living and meeting the vital needs;

2. Production organizational structure ensuring the development of the economy with the direct participation of the region's population;

3. Ecological and economic balance of the territory, that is, sustainable and steady development of agriculture with the use of intensive, but environmentally safe agricultural technologies preserving the environment.

Since rural areas are open systems, their management is not an autonomous closed structure. The process of managing rural areas is an integral element of the existing system of state and municipal government (Movchan and Yakovleva, 2017; Kuznetsov and Suprun, 2017; Semenov and Kuznetcov, 2015; Malarev et al., 2019; Shishlyannikov and Lavrenko, 2016; Nefedov, 2018; Ganieva et al., 2017). There are two outlines formed in the structure of rural areas management: the external one, where the state is the subject of management, and the internal one, where local and self-government and the economic authorities are the subjects of management (Pikulkin, 2010; Korableva et al., 2018). Therefore, the development of rural is exercised through the interaction of organizing and self-organizing foundations.

Consequently, it can be stated that the rural territories, which are controlled from the outside by the state, are under development, while this system continues selfdeveloping. The success of rural development depends on the correctness of external regulation and self-development rate. At the same time, the purpose of state 
Sustainable Development of Territories Based on the Integrated Use of Industry, Resource and Environmental Potential

154

authorities' activities is to create the prerequisites and conditions for selfdevelopment of the rural territories in the country's agrarian regions.

The agrarian-oriented region of the Altai Territory is characterized by a transboundary geo-economic position at the junction of the Kazakhstan, China and Mongolia borders, in direct contact with historically close countries and the growing markets of Central Asia, at the intersection of large migration and transcontinental transport flows. The unique nature of the regional resources and specific structure of the regional economy determine the complex of specific capabilities (in terms of realizing the potential of integration in the macro-region of Central Asia) and risks (due to the threat of disturbing the balance and security of the natural, social, economic and institutional systems) for sustainable development of the region for current and future generations of people (Sycheva et al., 2013; 2017; Gabidullina et al., 2018; Achaeva et al., 2018; Kayumova et al., 2019; Achaeva et al., 2015, 2016; Bittman et al., 2017). In this connection, the idea of creating a model and technology for sustainable development of the territories on the example of Altai region as an agrarian region of cross-border cooperation, which determines the achievement of positive social, environmental and economic effects of economic development, social sphere and the consumption of natural resources (Figure 1).

Figure 1. The main functions of rural areas (exemplified by the Altai Territory)

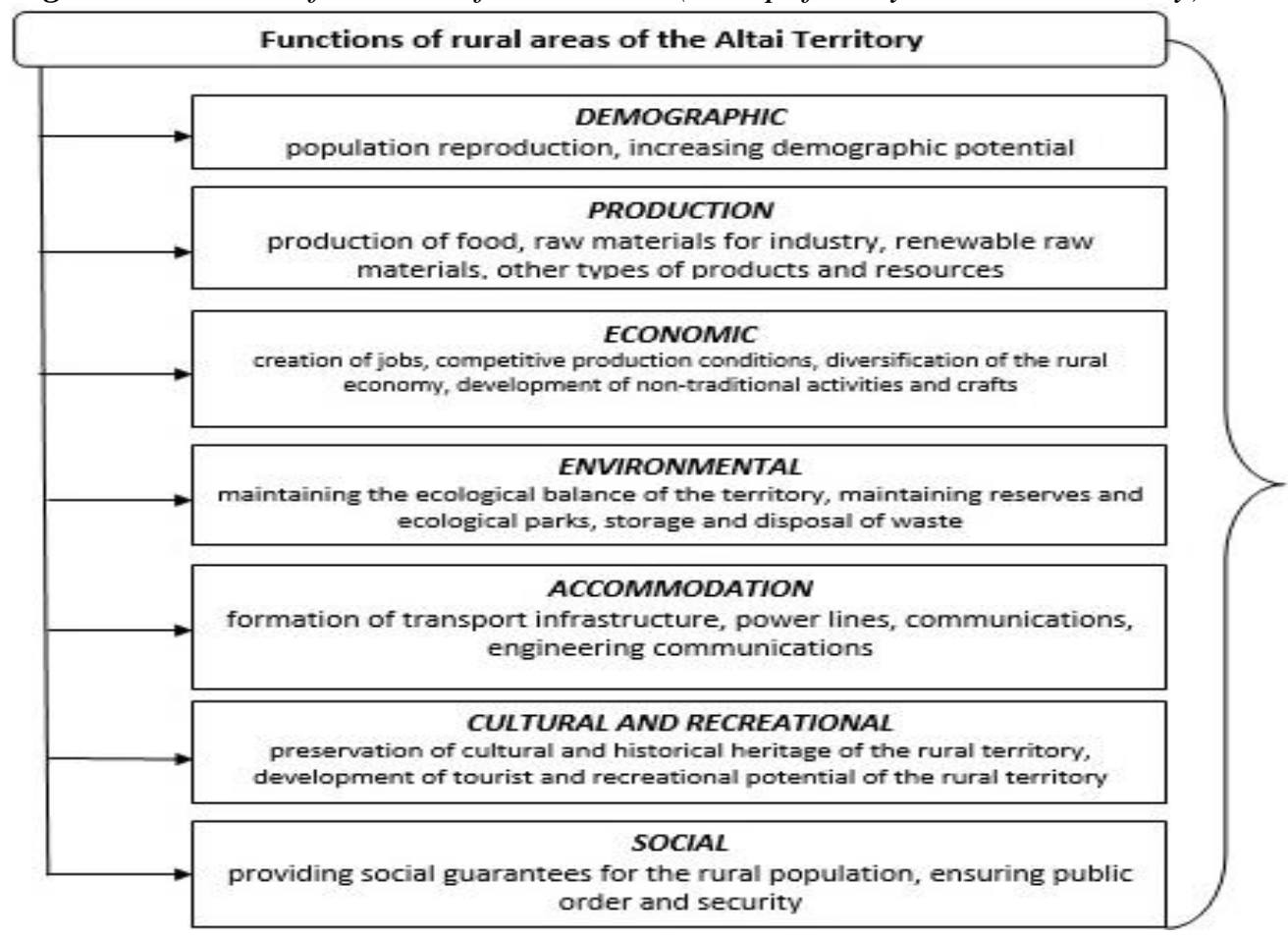


Rural municipal areas of the Altai Territory are developing territorial socioeconomic systems with irregular sustainability. The main issues of rural development that need to be addressed are:

- Low standard of living of the rural population in the region compared to the standard of living in the city of Barnaul - the capital of the Altai Territory, and the average standard of living in the country;

- Irrational use of land, recreational and labor resources of the territory;

- Unregulated partnership system between government, business and the public;

In rural areas of the Altai Territory, especially in the areas remote from the regional center, there is an acute problem of settling populations (Sultanova and Mardashov, 2016; Raupov and Podoprigora, 2017; Raupov and Korobov, 2018; Romashev and Aleksandrov, 2016; Aleksandrova and Shabarov, 2016). There is a stereotype, according to which, in order to get a better education, recreation, treatment, culture, utilities and other services people must leave the rural area. Young people are mostly moving to other regions of Russia. As a result, the strategy for ensuring the sustainable development of rural areas becomes a significant vector of socioeconomic development of the agriculture-oriented regions of Russia the Altai region. The main resources contributing to the implementation of sustainable development of rural areas are:

- Natural resource unit to the maximum extent adapted to the formation and maintenance of internal and external demand for territorial products and services;

- The principle of population distribution should remain unchanged, while the type of production and development of natural resources may be transformed. This will increase the efficiency and comfort of resource development while reducing the social burden of rural municipalities;

- Developing an effective system of self-organization for the local community through the strengthening of the local self-government system and the formation of civil institutions;

- Ensuring the energy independence of the rural areas at the expense of local fuel resources and renewable energy sources;

- Rational use of natural industrial and recreational reserves of the territory, compliance with the ecological balance;

- Developing transport infrastructure, confirming the geopolitical, socio-economic and recreational status of rural areas;

- Developing the service sector through small and medium-sized business support mechanisms;

- Positioning of agricultural production as a factor of potential development of the region's economy, providing and satisfying both its needs and the needs of urban agglomerations;

- Combining unique natural, historical monuments and the cultural heritage of rural 
areas should become a brand, a business card and a base for the development of tourism and recreation as a profitable sector of the economy.

In accordance with the above, the principal distinctive feature of strategic development for the rural territories is the approach to developing the region's territories through cluster networks. The technological chain may be local in nature and incomplete (shortened) or presented by a system of chains Koptev and Kopteva, 2017b; Lavrenko et al., 2019; Solnyshkina et al., 2014; Tananykhin et al., 2018; Vasiliev and Mardashov, 2017; Podoprigora and Raupov, 2018; Aleksandrova and Korchevenkov, 2017). The development of clusters in rural areas of the Altai Territory is hampered by a low level of labor skills, outdated technologies, lack of available capital and poor development of public institutions.

It should be noted that there is no standard version of the cluster. The cluster format directly depends on the specific location, available resources, their qualitative and quantitative characteristics, transport, logistics and information infrastructure, as well as on other factors. The mission of the rural territory is to achieve new standards for the quality of life of people with an effective combination of environmentally friendly industries with a unique natural complex. In territorial clusters, all processes related to planning, scientific substantiation, production, processing, storage, selling, certification of products (i.e. from a business idea to the final product) are combined in a single cycle. The territorial approach to the formation of clusters is due to significant differences of the regions' individual territories in their climatic potential, soil fertility, population density, level of infrastructure development, road accessibility, availability of markets for products, and the tourist and recreational potential of the area.

In our opinion, the formation of territorial clusters for the purposes of sustainable development of rural territories is of importance for the economic development of the agro-industrial region and the attraction of investment resources (Takhumova et al., 2018; Prischepa et al., 2018a, 2018b, 2018c; Prischepa and Averyanova, 2017; Kochneva, 2013; Kochneva et al., 2015). Moreover, public support will be important for the creation of territorial clusters and for building awareness of their role in the strategic development of the country's agriculture. It is advisable to include territorial clusters' support activities in the regional agriculture support programs, to ensure the environmental safety of the land use, to increase innovation level of the territories, to reduce tensions in the labor market, etc. Thus, the ecological state of the foothill zone of the Altai region, its tourist, recreational, land and resource potential were the main criteria for the choice of a given territory in the development of a territorial cluster project (Kopteva and Malarev, 2018, Vasilyev et al., 2018; Nefedov and Klepikov, 2018; Tarasova and Tarasov, 2018). This cluster is characterized by high soil productivity and relatively clean territory. It has all the necessary land and production prerequisites for creating a territorial cluster with the 
project name "Foothills of Altai". Today, there are several production enterprises and companies specializing on partial processing of organic agricultural products in the region, as well as enterprises specializing in the production of medicinal plant materials (herbs, roots, sea buckthorn). Moreover, all areas included in this zone are distinguished by a high level of cultural, tourist and recreational potential. The nature of this area attracts many tourists with clean lakes, waterfalls, mineral springs and many other beauties of the ecologically clean protected Altai foothills.

It is advisable to allocate the following sectors in the model of the territorial cluster: production and processing, supply, transport and logistics, service, marketing and sales, laboratory and certification, tourism and recreation and cultural and educational sector. To ensure the life of the cluster and the development of its additional activities, it is necessary to introduce the sector of management and coordination, finance and personnel, innovative and academic sectors (Tananykhin and Saychenko, 2017; Tananykhin and Khusainov, 2016; Sharifov and Mardashov, 2018; Ovcharenko et al., 2017; Akhmetshin et al., 2018; 2019). The research revealed that the distribution channels for the territorial cluster products may be different, including direct retail sales, medium wholesale and small wholesale sales, as well as large wholesale (Figure 2).

Figure 2. Estimated sales channels for the products of the "Foothills of Altai" cluster

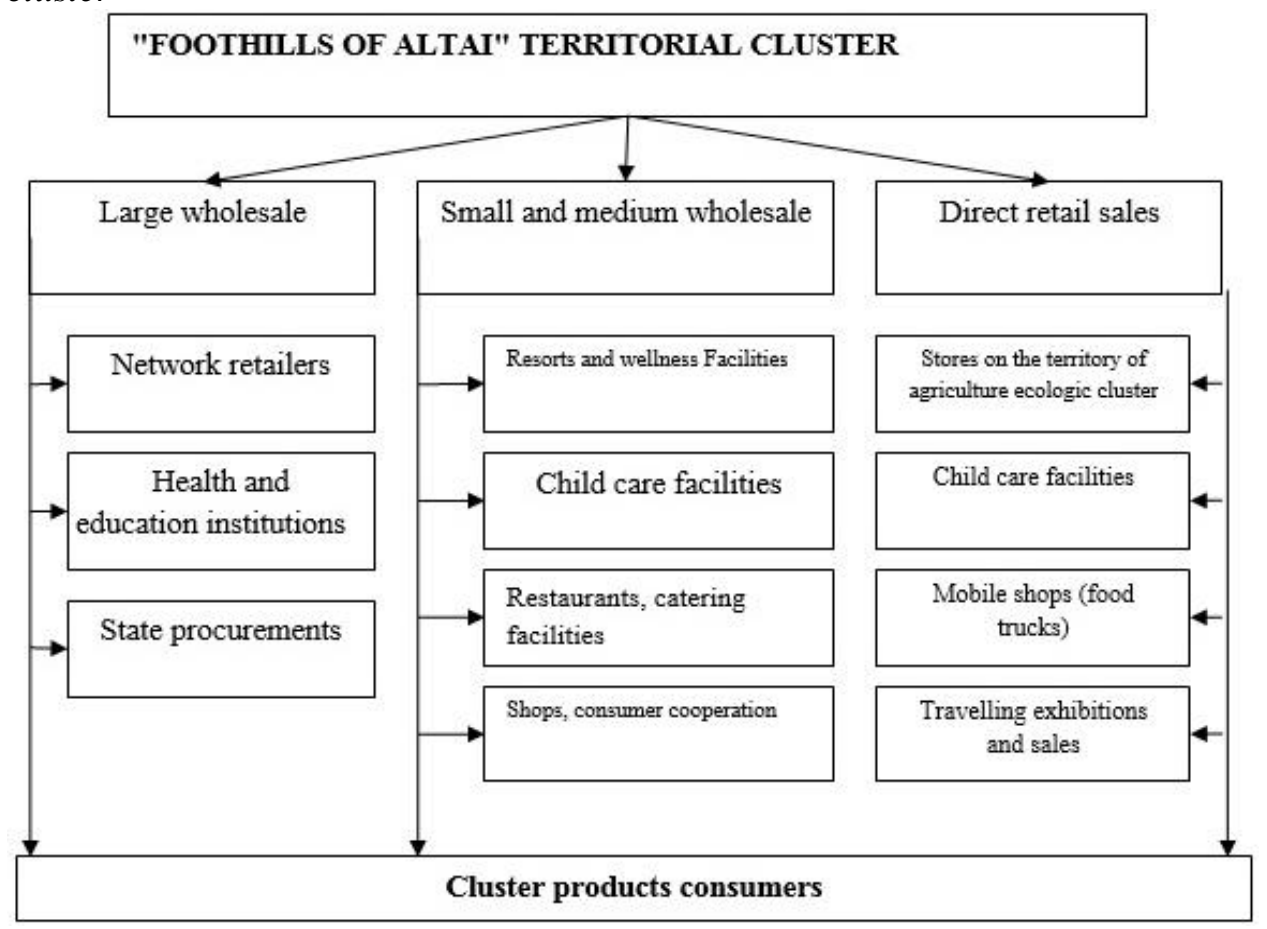


The territory of the foothill zone has a well-developed level of agricultural processing. There are numerous shops, retail outlets and catering establishments along the main tourist routes. Cooperation forms or vertically integrated formations, where the executive directorate or the leading processing enterprise serve as an integrator, can serve as organizational principles for the functioning of a territorial cluster.

\section{Conclusion}

In general, it should be noted that a smooth transition of some organizations to the principles of production, processing and provision of services in the format of territorial clusters requires successful experience in the operation of such cluster formations, as well as the appropriate level of information, organizational and financial support from regional and municipal authorities.

The authors believe that the activities of territorial clusters can have a significant positive effect on the level of economic, social and environmental development of rural administrative-territorial entities of the region by enhancing the regional market for both environmentally friendly and traditional agricultural products, full and environmentally balanced use of land resources, development of innovative agricultural technologies, increasing the level of employment of the rural population, activating the agricultural ecotourism, developing the ecological infrastructure of the territory, expanding the taxable base, and ensuring comprehensive sustainable development of the rural territories in the country's agricultural regions.

\section{References:}

Achaeva, M., Daurova, A., Pospelova, N. \& Borysov, V. 2018. Intercultural education in the system of training future teachers. Journal of Social Studies Education Research, 9(3), 261-281, doi:10.17499/jsser.48690.

Achaeva, M.S., Pospelov, S.A., Pospelova, N.V. \& Subbotina, N.S. 2016. Toponymic picture of scotland: Thesaurus approach. Journal of Organizational Culture, Communications and Conflict, 20, (Special Issue 1), 121-127.

Achayeva, M.S., Pospelova, N.V. \& Subbotina, N.S. 2015. Derivational slots of parametric adjectives: Cognitive aspect. Journal of Language and Literature, 6(3), 171-174, doi:10.7813/j11.2015/6-3/39.

Akhmetov, V.Ya., Barlybaev, A.A., Nasyrov, G.M. 2009. Tourism as a factor of diversification of rural economy. Forecasting problems, 6(117), 105-111.

Akhmetshin, E.M., Barmuta, K.A., Yakovenko, Z.M., Zadorozhnaya, L.I., Mironov, D.S. \& Klochko, E.N. 2017a. Advantages of cluster approach in managing the economy of the Russian federation. International Journal of Applied Business and Economic Research, 15(23), 355-364.

Akhmetshin, E.M., Kolpak, E.P., Sulimova, E.A., Kireev, V.S., Samarina, E.A. \& Solodilova, N.Z. 2017b. Clustering as a criterion for the success of modern 
industrial enterprises. International Journal of Applied Business and Economic Research, 15(23), 221-231.

Akhmetshin, E.M., Kovalenko, K.E., Goloshchapova, L.V., Polyakova, A.G., Erzinkyan, E.A. \& Murzagalina, G.M. 2018. Approaches to social entrepreneurship in Russia and foreign countries. Journal of Entrepreneurship Education, 21, (Special Issue 2).

Akhmetshin, E.M., Romanov, P.Y., Zakieva, R.R., Zhminko, A.E., Aleshko, R.A. \& Makarov, A.L. 2019. Modern approaches toinnovative project management in entrepreneurship education: a review of methods and applications in education. Journal of Entrepreneurship Education, 22, (Special Issue 1).

Aleksandrova, T.N., Nikolaeva, N., Romashev, A. 2015. An experimental and theoretical approach to the assessment of the specific surface of apatite-nepheline ore in the process of grinding. International Multidisciplinary Scientific GeoConference Surveying Geology and Mining Ecology Management, SGEM2015, 577-583.

Aleksandrova, T.N., Arustamyan, K.M. \& Romanenko, S.A. 2017. The mathematical analysis methods application in estimation of the international practice of copperzinc and pyritic-polymetallic ores selective flotation. Obogashchenie Rud, (5), 2127, doi:10.17580/or.2017.05.04.

Aleksandrova, T.N. \& Korchevenkov, S.A. 2017. Ecological and technologycal aspects of ash and slag wastes utilization. Journal of Ecological Engineering, 18(4), 15-24, doi:10.12911/22998993/74363.

Aleksandrova, T.N. \& Shabarov, A.N. 2016. Key issues for improving of carbonaceous ore beneficiation processes for the extraction of valuable components. XVIII international coal preparation congress: 28 june-01 july 2016 Saint-Petersburg, Russia, 1179-1183, doi:10.1007/978-3-319-40943-6_185.

Alferova, T.V. 2015. Conceptual modeling of the category of «sustainable development». Journal of Economic Theory, 4, 46-52.

Bittman, B., Davies, A., Russell, W. \& Goussakova, E. 2017. Advance Placement and the Achievement Gap in the 21st Century: A Multiple Linear Regression of Marginalized Populations in AP Enrollment. Research in Social Sciences and Technology, 2(2), http://ressat.org/index.php/ressat/article/view/46.

Danilov-Danilian, V.I. 2003. Sustainable development. Theoretical and methodological analysis. Economics and Mathematical Methods, 8(24), 123-135.

Gabidullina, F., Zhundibayeva, A., Makarova, V., Galiullin, R. \& Mubarakshina, I. 2018. The realization of the hermeneutical approach to the text in practical classes in the literature during the work with students of philological faculty. Journal of Social Studies Education Research, 9(3), 226-240, doi:10.17499/jsser.32940.

Ganieva, I.A., Churin, A.N., Melnikov, A.B., Mikhaylushkin, P.V. \& Poltarykhin, A.L. 2017. Development of the meat market in russia. Espacios, 38(48).

Ivanova, V.N., Atyukova, O.K. \& Poltarykhin, A.L. 2018. Prerequisites of growth of investment and social attractiveness of the regions of russia within the framework of implementation of the public-private partnership projects. International Journal of Mechanical Engineering and Technology, 9(11), 2299-2305.

Kayumova, G., Sheymardanov, S., Akhtarieva, R., \& Zhundibayeva, A. 2019. Developing creative potential of a schoolchild by means of native language. Journal of Social Studies Education Research, 10(1), 81-92.

Kolesova, Yu.N. 2015. Strategy of sustainable development of rural areas. Young scientist, 8, 392-394. 
Kovalenko, E.G. 2012. Problems and mechanisms of development of rural territorie. Fundamental research, 3-3, 687-690.

Kopteva, A.V. \& Koptev, V.Y. 2018. Automatic measuring system for oil stream paraffin deposits parameters. Paper presented at the IOP Conference Series: Materials Science and Engineering, 327(4), doi:10.1088/1757-899X/327/4/042053.

Koptev, V.Y. \& Kopteva, A.V. 2017a. Structure of energy consumption and improving openpit dump truck efficiency. Paper presented at the IOP Conference Series: Earth and Environmental Science, 87(2), doi:10.1088/1755-1315/87/2/022010.

Koptev, V.Y. \& Kopteva, A.V. 2017b. Improving paraffin deposits detection methodology for better ecological safety during hydrocarbon transportation. International Journal of Applied Engineering Research, 12(5), 618-621.

Kopteva, A.V. \& Malarev, V.I. 2018. Studying thermal dynamic processes in an isolated type borehole electrode heater for high-viscosity oil extraction. Paper presented at the Proceedings of the 2018 IEEE Conference of Russian Young Researchers in Electrical and Electronic Engineering, ElConRus 2018, January 678-681, doi:10.1109/EIConRus.2018.8317185.

Korableva, O.N., Kalimullina, O.V., Zaytseva, A.A. \& Larionov, A.I. 2018. Elaboration of database for the subject domain of innovation and economic growth potential. Paper presented at the Proceedings of the 31st International Business Information Management Association Conference, IBIMA 2018: Innovation Management and Education Excellence through Vision 2020, 6065-6073.

Korobov, G. \& Podoprigora, D. 2018. Depth computation for the onset of organic sedimentation formation in the oil producing well as exemplified by the sibirskoye oil field. Acta Technica CSAV (Ceskoslovensk Akademie Ved), 63(3), 481-492.

Korobov, G. \& Raupov, I. 2017. Study of adsorption and desorption of asphaltene sediments inhibitor in the bottomhole formation zone. International Journal of Applied Engineering Research, 12(2), 267-272.

Kochneva, O.E. 2013. Classification of carbonate rocks as a basis regional facial analysis. Neftyanoe Khozyaystvo - Oil Industry, (4), 10-12.

Kochneva, O.E., Karaseva, T.V. \& Kuznetsova, E.A. 2015. Prospects of oil-and-gas content of the deep-shipped deposits of the verkhnepechorsky hollow by data basin modeling. Neftyanoe Khozyaystvo - Oil Industry, (3), 14-16.

Kuznetsov, V.S. \& Suprun, I.K. 2017. Reduction of an adverse impact during well drilling by means of drilling waste usage. Journal of Ecological Engineering, 18(2), 12-15, doi:10.12911/22998993/68211.

Lavrenko, S.A., Shishljannikov, D.I., Maksimov, A.B. 2019. Energy efficient unit executive body for tunneling and cleaning operations. Innovation-Based Development of the Mineral Resources Sector: Challenges and Prospects - 11th conference of the Russian-German Raw Materials, 287-292.

Malarev, V.I., Kopteva, A.V. \& Koptev, V.Y. 2019. Electric power supply system development for down-hole electric steam generators to produce high-viscosity oil. Paper presented at the 2018 International Multi-Conference on Industrial Engineering and Modern Technologies, FarEastCon 2018, doi:10.1109/FarEastCon.2018.8602954.

Movchan, I.B., Yakovleva, A.A. 2017. Experience of qualitative and quantitative interpretation of nonpotential geofields with surface and deep morphostructural reconstructions on the example of unica ore province (Kareljya, Russia). 
International Journal of Mechanical Engineering and Technology, 8(12), 926-932.

Nagimov, A.R., Akhmetshin, E.M., Slanov, V.P., Shpakova, R.N., Solomonov, M.P. \& Il'yaschenko, D.P. 2018. Foresight technologies in the formation of a sustainable regional development strategy. European Research Studies Journal, 21(2), 741-752.

Nefedov, Y. 2018. The arctic shelf and hard to recover oil reserves as alternative development of russian resource base. Paper presented at the Saint Petersburg 2018: Innovations in Geosciences.

Nefedov, Y.V. \& Klepikov, I.V. 2018. Occurrence regularities of nitrogen defects in the ural type crystal diamonds from different regions, doi:10.4028/www.scientific.net/KEM.769.201.

Nikolaeva, N., Aleksandrova, T., Romashev, A. 2018. Effect of grinding on the fractional composition of polymineral laminated bituminous shales. Mineral Processing and Extractive Metallurgy Review, 39(4), 231-234, DOI:

10.1080/08827508.2017.1415207.

Ovcharenko, Y.V., Gumerov, R.R., Bazyrov, I.S., Kunakova, A.M., Mardashov, D.V., Gunkin, A.S. \& Legkokonets, V.A. 2017. Well killing specifics in conditions of fractured and porous carbonate reservoirs of the eastern part of the orenburgskoye oil-gas-condensate field. Neftyanoe Khozyaystvo - Oil Industry, (12), 52-55.

Pikulkin, A.V. 2010. The system of government administration. Moscow: Unity-Dana, 639.

Podprugin, M.O. 2012. Sustainable development of the region: the concept, the basic approaches and the factors. Journal of Russian entrepreneurship, 24, 214-221.

Poltarykhin, A.L., Alekseev, A.E., Kudryavtsev, V.V., Makhanova, T.A., Voronkova, O.Yu., Aydinov, H.T. 2018. Prospects for the Development of the Green Economy of Russian Federation. European Research Studies Journal, 21(4), 470-479.

Polushkina, T.M. 2012. Formation of a rational system of state regulation of agrarian sector of economy meeting the requirements of cost-effective agricultural policy. Basic research, 9-4, 976-980.

Polyakova, A.G., Akhmetshin, E.M., Goloshchapova, L.V., Rakhmeeva, I.I., Noeva, E.E. \& Rakovskiy, V.I. 2018. A model of regional economic space modernization. European Research Studies Journal, 21, (Special Issue 2), 624-634.

Podoprigora, D. \& Korobov, G. 2017. Selection of the acidizing compositions for use in terrigenous reservoirs with high carbonate content. International Journal of Applied Engineering Research, 12(2), 249-255.

Podoprigora, D. \& Raupov, I. 2018. Research of the influence of polymeric drilling mud on the filtration-capacitive properties of polymictic sandstones. Acta Technica CSAV (Ceskoslovensk Akademie Ved), 63(4), 537-546.

Podoprigora, D. \& Saychenko, L. 2017. Development of acid composition for bottom-hole formation zone treatment at high reservoir temperatures. Espacios, 38(48).

Podoprigora, D.G., Shangaraeva, L.A., Usenkov, A.V. \& Ilyushin, P.Y. 2016. Development of acid composition for bottom-hole formation zone treatment at high reservoir temperatures. Neftyanoe Khozyaystvo - Oil Industry, (4), 122-124.

Prischepa, O., Bogatsky, V., Chumakova, O., Shaburova, M. \& Kuranov, A. 2018a. Improving of geological petroleum zoning of the northern timan-pechora province. Paper presented at the Saint Petersburg 2018: Innovations in Geosciences.

Prischepa, O., Chumakova, O., Zemlyakov, A., Orlova, L. \& Blinkova, E. 2018b. Assessment of petroleum exploration activity performed in the timan-pechora petroleum province. Paper presented at the Saint Petersburg 2018: Innovations in 
Geosciences.

Prischepa, O., Grokhotov, E., Makarova, I., Averyanova, O. \& Nikiforova, V. 2018c. Petroleum prospects of the domanik formation in timano-pechora province. Paper presented at the Saint Petersburg 2018: Innovations in Geosciences.

Prischepa, O.M. \& Averyanova, O.Y. 2017. Approaches to the hydrocarbon potential evaluation of the shale strata, domanik deposits of timan-pechora province. Paper presented at the EAGE/SPE Joint Workshop on Shale Science 2017: Prospecting and Development.

Raupov, I. \& Podoprigora, D. 2017. Laboratory researches of the polymeric composition in the pore space of bulk models. International Journal of Applied Engineering Research, 12(3), 365-371.

Raupov, I.R. \& Korobov, G.Y. 2018. Research of polymer compositions rheological properties for oil production. Acta Technica CSAV (Ceskoslovensk Akademie Ved), 63(3), 493-500.

Romashev, T.N. \& Aleksandrov, A.V. 2016. About modeling of rheological properties of heavy oil suspensions. Neftyanoe Khozyaystvo - Oil Industry, (5), 68-70.

Rozenberg, N.V. 2005. Socio-cultural component of the concept «region». Analytics of cultural science, 2(4), 34-43.

Semenov, A.S. \& Kuznetcov, V.S. 2015. Assessment of level of risk in decision-making in terms of career exploitation. International Journal of Economics and Financial Issues, 5(3S), 165-172.

Sharifov, A.R. \& Mardashov, D.V. 2018. Liquid solvent addition to steam for enhancing recovery of heavy oil with cyclic steam stimulation. Paper presented at the Saint Petersburg 2018: Innovations in Geosciences.

Shishlyannikov, D.I., Lavrenko, S.A. 2016. Research of the mine shuttle car VS-30 drive mode. ARPN Journal of Engineering and Applied Sciences, 11(23), 13941-13944.

Sozinova, A.A., Okhrimenko, O.I., Goloshchapova, L.V., Kolpak, E.P., Golovanova, N.B. \& Tikhomirov, E.A. 2017. Industrial and innovation clusters: Development in Russia. International Journal of Applied Business and Economic Research, 15(11), 111-118.

Solnyshkina, M.I., Harkova, E.V. \& Kiselnikov, A.S. 2014. Unified (Russian) state exam in english: Reading comprehension tasks. English Language Teaching, 7(12), 1-11, doi:10.5539/elt.v7n12p1.

Sultanova, D. \& Mardashov, D. 2016. Research of the effect of scale inhibitors on the effectiveness of corrosion inhibitors in oil wells. International Journal of Applied Engineering Research, 11(18), 9460-9463.

Sycheva, I.N., Ovchinnicov, Y.L., Voronkova, O.Y., Akhmetshin, E.M., Kolmakov, V.V. \& Vasilieva, A.G. 2018. Economic potential and development prospects of small businesses in rural areas. European Research Studies Journal, 21(4), 292-303.

Sycheva, I.N., Ovchinnikov, Y.L., Permyakova, E.S., Voronkova, O.Yu. 2017. Organic Production at Long-fallow Lands as a Strategic Resource of the Food Import Substitution Policy. Revista Espacios, 38(33), 40.

Sycheva, I.N., Permyakova, E.S., Voronkova O.Yu. \& Kuzmina, N.N. 2015. "Green box" and innovative development of the regional agricultural sector. Biosciences Biotechnology Research Asia, 12(1), 181-190.

Takhumova, O.V., Kasatkina, E.V., Maslihova, E.A., Yumashev, A.V. \& Yumasheva, M.V. 2018. The main directions of increasing the investment attractiveness of the Russian regions in the conditions of institutional transformations. Espacios, 39(37). 
Tarasova, F.K. \& Tarasov, A.M. 2018. The phraseosemantic group of "family relations" in the system of proverbs and sayings with "food" component in languages with different structures. Analele Universitatii Din Craiova - Seria Stiinte Filologice, Lingvistica, 40(1-2), 191-201.

Tananykhin, D., Tcvetkov, P., Kamoza, V. 2018. Analysis and Recommendations of Sand Consolidation Methods to Limit Sand Production in Gas Wells. Journal of Physics: Conf. Series, 1072, 012022, doi :10.1088/1742-6596/1072/1/012022.

Tananykhin, D., Saychenko, L. 2017. Sand control methods for the development of oil \& gas fields with hard to recover reserves. Espacios (ISSN: 07981015), 38(48), 31.

Tananykhin, D., Khusainov, R. 2016. Diffusion of nonionic surfactants diffusion from aqueous solutions into viscous oil. Petroleum Science and Technology, 34(24), 1984-1988, doi: 10.1080/10916466.2016.1233245.

Vasilyev, A.L., Lavrenko, S.L., Gruszczynski, M. 2018. Experimental studies of rheological properties of stowing pulps. Journal of Physics: Conference Series, 1118(1).

Vasiliev, B.U. \& Mardashov, D.V. 2017. Methods and tools for education and research in the information society. Paper presented at the Proceedings of the 2017 International Conference "Quality Management, Transport and Information Security, Information Technologies", IT and QM and IS 2017, 699-703.

Voronkova, O.Y., Akhmetshin, E.M., Sycheva, I.N., Shpakova, R.N., Pashkova, E.Y. \& Poltarykhin, A.L. 2018a. Economic mechanism of regulating land relations in the agricultural sector of Russia. European Research Studies Journal, 21(4), 280-291.

Voronkova, O.Y., Ovchinnicov, Y.L., Sycheva, I.N., Kolomeytseva, A.A., Marchuk, V.I. \& Osadtchij, E.A. 2018b. Economic efficiency and resource potential of organic production in Russia. International Journal of Mechanical Engineering and Technology, 9(10), 900-909.

Voronkova, O.Y., Zadimidcenko, A.M., Goloshchapova, L.V., Polyakova, A.G., Kamolov, S.G. \& Akhmetshin, E.M. 2018c. Economic and mathematical modeling of regional industrial processes. European Research Studies Journal, 21(4), 268-279.

Yarlykapov, A.D. 2013. Assessment of regional development forecasting options. Regional economy, 2(34), 23-31. 